\title{
Kinetics and Mechanism of Ruthenium(III) Catalyzed Oxidation of L- Proline by Hexacyanoferrate(III) in Aqueous Alkali
}

\author{
K. Sharanabasamma, Mahantesh A. Angadi and Suresh M. Tuwar*
}

Department of Chemistry, Karnatak Science College, Dharwad-580 001, Karnataka, India

\begin{abstract}
Kinetics of ruthenium(III) catalyzed oxidation of L-proline by hexacyanoferrate(III)(HCF) in alkali was studied spectrophotometrically at $30^{\circ} \mathrm{C}$. A reaction was found to be independent upon [L-proline]. The reaction was occurred without intervening free radical. Since unit order each in $[\mathrm{Ru}(\mathrm{III})]$ and $[\mathrm{HCF}]$, the oxidation follows an outer-sphere mechanism. A suitable mechanism was proposed and rate law was derived as$$
\mathrm{k}_{\mathrm{obs}}=\frac{\mathrm{k} \mathrm{K}_{1}\left[\mathrm{Ru}(\mathrm{III})\left[\mathrm{OH}^{-}\right]\right.}{1+\mathrm{K}_{1}\left[\mathrm{OH}^{-}\right]}
$$

The rate constant, ' $\mathrm{k}$ ' and equilibrium constant ' $\mathrm{K}_{1}$ ' of the prior equilibrium step of reaction,

$$
\left[\mathrm{Ru}\left(\mathrm{H}_{2} \mathrm{O}\right)_{6}\right]^{3+}+\mathrm{OH}^{-} \rightleftharpoons\left[\mathrm{Ru}\left(\mathrm{H}_{2} \mathrm{O}\right)_{5}\left(\mathrm{OH}^{-}\right)\right]^{2+}
$$

were calculated. The oxidative product of L- proline was analyzed quantitatively as L-glutamic acid. Activation parameters were evaluated.
\end{abstract}

Keywords: Ruthenium(III), L-proline, hexacyanoferrate(III), catalysis, ruthenium(III) complexes.

\section{INTRODUCTION}

Amino acids derived largely from protein in the diet or degradation of intracellular proteins are the final class of biomolecules whose oxidation makes a significant contribution to the generation of metabolic energy. Depending upon the number of carbon atoms in the $\alpha$-amino acids moiety, they are oxidized to $\alpha$-keto glutamate, succinates, fumerate and oxaloacetate etc. L-proline is one of the $20 \alpha$-amino acids with five-carbon atoms in pyrrolidine skeleton. This pyrrolidine ring is opened [1] by oxidation at the carbon atom most distant from the carboxylic group to create a Schiff's base and hydrolysis of this Schiff's base leads to a linear glutamic semi-aldehyde. This is further oxidized the at the same carbon to produce glutamic acid. However, the earlier reports [2] reveal that L-proline undergoes oxidation with the cleavage of pyrrolidine ring at the closest carbon atom from the carboxylic acid group followed by decarboxylation to give 4-amino butanol or 4-amino butyric acid, whereas D- proline leads to keto acid. Since L-proline has a cyclic structure with an imino [3] group attached at one end by $-\mathrm{CH}_{2}$ and at other end by $>\mathrm{CH}-\mathrm{COOH}$, the cleavage at the closest carbon atom from carboxylic group is unusual. This may also be due to the least reactivity of $\alpha$ carbon/hydrogen. Hence, the ring opening takes place at a carbon atom of far end from carboxylic group. Moreover, when $-\mathrm{NH}_{2}$ group is not remaining at $\alpha$-carbon atom, there is no other driving force remains for decarboxylation to give butaraldehyde, butyric acid or keto acids. Hence, in order to examine the path following in the oxidative ring cleavage in L-proline, a most suitable oxidant like hexacyanoferrate(III) (HCF) is used along with a catalyst, ruthenium(III).

*Address correspondence to this author at the Department of Chemistry, Karnatak Science College, Dharwad-580 001, Karnataka, India;

Tel: +919449796557; E-mail: sm.tuwar@gmail.com
Many transition and non-transition metal ions in their complex form act as good oxidants in acidic, basic or neutral medium. However, oxidation capacity is depending upon their redox potential. It is also known that the redox potential of the couple is depending upon the $\mathrm{pH}$ of the medium. For instance, the redox potential [4] of $\left[\mathrm{Fe}(\mathrm{CN})_{6}\right]^{3-} /\left[\mathrm{Fe}(\mathrm{CN})_{6}\right]^{4-}$ in acid medium is $+0.36 \mathrm{~V}$ and in basic medium $+0.40 \mathrm{~V}$. This indicates that the HCF is a good oxidant in basic medium. Hence, it is widely used to study the mechanism for oxidation of many organic compounds. The oxidation of such organic compounds is followed by outer-sphere mechanism [5]. Moreover, HCF is single equivalent and stable oxidant, it adds less error to the experimental results, and data can be analyzed meticulously to establish the reaction path. In most of the oxidations, HCF is mainly used as hydrogen atom abstractor [6,7] and/or free radical generator [8]. It is used as an electron abstracting reagent $[9,10]$ also. In view of this and the contradicting facts about the oxidation paths of L-proline, HCF is used as an oxidant in presence of trace amount of $\mathrm{Ru}($ III) as a catalyst, the present investigation is undertaken.

Although, both osmium and ruthenium belong to the same group, their compounds are stable in different oxidation states. Osmium compounds are highly stable in +8 oxidation state where as ruthenium compounds are in +3 or + 4. Hence, their catalytic role varies to a large extent; in most of the oxidations [11] of organic compounds, the reaction was independent upon substrate concentration in $\mathrm{Ru}(\mathrm{III})$ catalysis and unity or fractional order in Os(VIII) catalysis. This may be due to the large difference in their redox potentials. The redox potentials of $\mathrm{Ru}(\mathrm{IV}) / \mathrm{Ru}(\mathrm{III})$ is $+1.3 \mathrm{~V}$ which is unexpectedly higher than that of Os(VIII)/Os(VI) of $+0.85 \mathrm{~V}$. This suggests that the ruthenium is a good catalyst in +3 state. Apart from this and the fact that the substrates are oxidized by two equivalent change in the form of hydride ion $[12,13,14]$ abstraction in $\mathrm{Ru}(\mathrm{III})$ catalysis, irrespective of 
one equivalent or two equivalent oxidants used. Hence, to understand the reaction path of L-proline in the formation of L-glutamic acid, a single equivalent oxidant, $\mathrm{HCF}$ and $\mathrm{Ru}(\mathrm{III})$ as a catalyst are used.

\section{EXPERIMENTAL}

\subsection{Materials and Reagents}

All chemicals used were of reagent grade. HCF solution was obtained by dissolving an appropriate amount of $\mathrm{K}_{3}\left[\mathrm{Fe}(\mathrm{CN})_{6}\right] \quad(\mathrm{BDH})$ in double distilled water. Its concentration was assayed iodometrically [15]. Recrystallized sample of L-proline was dissolved in water to get required concentration. It is standardized colorimetrically [16] in presence of ninhydrin. The ruthenium(III) solution was prepared by dissolving a known mass of $\mathrm{RuCl}_{3}$ (s.d.finechem) in $0.2 \mathrm{~mol} \mathrm{dm} \mathrm{dCl}^{-3} \mathrm{Hercury}$ was added to ruthenium(III) solution to reduce any ruthenium(IV) formed during the preparation of the ruthenium(III) stock solution and kept for about $24 \mathrm{hrs}$. Its concentration was ascertained [17] by EDTA titration. Aqueous solution of $\mathrm{NaOH}$ and $\mathrm{NaNO}_{3}$ were used to maintain required concentration of alkali and ionic strength respectively in the reaction medium unless otherwise stated. Aqueous solutions of $\left[\mathrm{K}_{4}\left[\mathrm{Fe}(\mathrm{CN})_{6}\right]\right.$ and L-glutamic acid were used to study the product effect.

\subsection{Kinetics Measurements}

The reaction was initiated by mixing $\mathrm{K}_{3}\left[\mathrm{Fe}(\mathrm{CN})_{6}\right]$ solution to L-proline which also contained required amounts of $\mathrm{Ru}(\mathrm{III}), \mathrm{NaOH}$ and $\mathrm{NaCl}$. The reaction was studied at $25 \pm$ $1^{0} \mathrm{C}$ under pseudo-first order condition where [L-Prol] > $[\mathrm{HCF}]$ at least 10 times. Progress of the reaction was followed spectrophotometrically by measuring decrease in the absorbance of HCF at its $\lambda_{\max } 420 \mathrm{~nm}$. The pseudo- first order rate constants, $\mathrm{k}_{\mathrm{obs}}$ were calculated from the slopes of $\log [\mathrm{HCF}]$ versus time plots which were linear up to $60 \%$ completion of the reaction in most of the variation of concentrations of oxidant, reductant and catalyst. The nonlinearity above $60 \%$ is discussed elsewhere. Order with respect to each reactant is determined from the slopes of plots of $\log \mathrm{k}_{\mathrm{obs}}$ versus $\log$ (conc.) except in [HCF]. The results were reproducible within $\pm 4 \%$.

Since a moderate concentration of alkali used in the present investigation, the effect of dissolved $\mathrm{CO}_{2}$ on the reaction was studied by conducting the experiments parallel to the air and in inert atmosphere $\left(\mathrm{N}_{2}\right)$. It was found that a negligible difference in the rate constants was observed in presence and absence of air.

\section{RESULTS}

\subsection{Stoichiometric and Product Analysis}

Different sets of various concentrations of reactants, at a constant [Ru(III)] in $0.02 \mathrm{~mol} \mathrm{dm}^{-3} \mathrm{NaOH}$ at a constant ionic strength of $0.1 \mathrm{~mol} \mathrm{dm}^{-3}$ were kept for over $24 \mathrm{hrs}$ at $25^{\circ} \mathrm{C}$. After completion of reaction, when $[\mathrm{HCF}]>[\mathrm{L}-\mathrm{Prol}]$ the unreacted $[\mathrm{HCF}]$ was analyzed by measuring its absorbance at $420 \mathrm{~nm}$ spectrophotometrically. It was also estimated iodometrically. The main oxidative product of L- proline was identified as L-glutamic acid by its spot test [18] in which the intense blue color was obtained by adding Ninhydrin. It is also estimated quantitatively as ninhydrin derivative by spectrophotometric method [16]. It is found that L-proline was oxidized to L-glutamic acid. Other plausible products like glutamic semialdehyde and $\alpha$-keto acid were not found. Further, the L-glutamic acid was separated from reaction mixture by ether extraction on acidification and subjected to IR scanning. It was observed that the stretching frequencies of $-\mathrm{NH}_{2},-\mathrm{COOH}$ and carbonyl were appeared to be $3430 \mathrm{~cm}^{-1}, 3060 \mathrm{~cm}^{-1}$ and 1684 $\mathrm{cm}^{-1}$ respectively and $\mathrm{C}-\mathrm{N}$ vibration frequencies at $1124 \mathrm{~cm}^{-1}$ was also observed. This clearly indicates that the oxidative product of L-proline was found to be L-glutamic acid which is formed by reacting with 4 moles of $\left[\mathrm{Fe}(\mathrm{CN})_{6}\right]^{3-}$ as shown in Equation 1.

$$
\begin{aligned}
& \underset{\substack{\mathrm{H} \\
\mathrm{H}}}{\mathrm{COO}^{-}}+4\left[\mathrm{Fe}\left(\mathrm{CN}_{6}\right]^{3+}+5 \mathrm{OH}-\stackrel{\mathrm{Ru}(\mathrm{III})}{\longrightarrow} \overline{\mathrm{OOC}} \cdot \mathrm{CH}_{2}-\mathrm{CH}_{2}-\underset{\mathrm{NH}_{2}}{\mathrm{CH}}-\mathrm{COO}^{-}\right. \\
& +4\left[\mathrm{Fe}\left(\mathrm{CN}_{6}\right]^{4+}+3 \mathrm{H}_{2} \mathrm{O}\right.
\end{aligned}
$$

\subsection{Reaction Order}

The orders of the various reactants were determined from the plots of $\log \left(\mathrm{k}_{\mathrm{obs}}\right)$ versus $\log$ (Conc.) except in $[\mathrm{HCF}]$ by varying the concentrations of oxidant, reductant, catalyst and alkali in turn, while keeping others constant in the variation of each reactant.

The $[\mathrm{HCF}]$ was varied from $6.0 \times 10^{-5}$ to $7.0 \times 10^{-4} \mathrm{~mol}$ $\mathrm{dm}^{-3}$ at constant concentrations of L-proline, ruthenium(III), $\mathrm{OH}^{-}$and ionic strength (Table 1). The pseudo- first order plot of $\log [\mathrm{HCF}]$ versus time was linear up to $60 \%$ of reaction and slope at linear portion was found to be constant for all the varied $[\mathrm{HCF}]$. Thus, order in $[\mathrm{HCF}]$ is considered as unity.

The pseudo-first order plots for the various concentrations of L-proline were also linear with nonvariation in the slopes which indicates that the rate of reaction was independent upon the [L-Prol]. Hence, the order in L-proline was zero in the concentration range studied from $1.0 \times 10^{-3}$ to $1.0 \times 10^{-2} \mathrm{~mol} \mathrm{dm}^{-3}$ (Table $\mathbf{1}$ ).

The effect of $\left[\mathrm{OH}^{-}\right]$at fixed ionic strength of $0.1 \mathrm{~mol} \mathrm{dm}^{-3}$ on the rate of reaction was studied by varying the concentration of $\mathrm{NaOH}$ in the concentration range, 0.005 to $0.08 \mathrm{~mol} \mathrm{dm}^{-3}$ at constant concentrations of $\mathrm{HCF}, \mathrm{L}-$ proline and $\mathrm{Ru}(\mathrm{III})$. The ' $\mathrm{k}_{\mathrm{obs}}$ ' were increased with increase in $\left[\mathrm{OH}^{\prime}\right]$ (Table 1). From the $\log -\log$ plot of $\mathrm{k}_{\mathrm{obs}}$ and $\left[\mathrm{OH}^{-}\right]$, the order in $\left[\mathrm{OH}^{-}\right]$was determined as $\approx 0.7$.

\subsection{Effect of Added Products}

The effect of initially added products, $\left[\mathrm{Fe}(\mathrm{CN})_{6}\right]^{4-}$ and Lglutamic acid were studied in the concentration range, $8.0 \mathrm{x}$ $10^{-5}$ to $7.0 \times 10^{-4} \mathrm{~mol} \mathrm{dm}^{-3}$ at a fixed concentration of oxidant, alkali, reductant and catalyst (Table 2 ). The initially added L-glutamic acid did not alter the rate of reaction whereas added $\mathrm{K}_{4}\left[\mathrm{Fe}(\mathrm{CN})_{6}\right]$ had retarding effect on the rate of reaction and order was calculated to be -0.6. In view of the retardation of rate with initial addition of $\left[\mathrm{Fe}(\mathrm{CN})_{6}\right]^{4-}$ added in the form of $\mathrm{K}_{4}\left[\mathrm{Fe}(\mathrm{CN})_{6}\right]$, the effect of $\mathrm{K}^{+}$on the rate was also studied by varying the $[\mathrm{KCl}]$ in the same concentration range that of $\mathrm{K}_{4}\left[\mathrm{Fe}(\mathrm{CN})_{6}\right]$. The added $\mathrm{KCl}$ did not alter the rate of reaction. Hence, retardation on the rate of reaction was due to $\left[\mathrm{Fe}(\mathrm{CN})_{6}\right]^{4-}$ only. Further, the non influencing effect of $\mathrm{Cl}^{-}$on the rate of reaction is ascribable that $\mathrm{Ru}(\mathrm{III})$ is not existed in its chloride complex forms. 
Table 1. Effect of Variation of [HCF], [L-Prol], [OH'] and [Ru(III)] on Oxidation of L-Proline by Hexacyanoferrate(III) Catalyzed by Ruthenium(III) in Aqueous Alkali at $25^{\circ} \mathrm{C}$ and $\mathrm{I}=0.1 / \mathrm{mol} \mathrm{dm}^{-3}$

\begin{tabular}{|c|c|c|c|c|c|}
\hline $\begin{array}{c}{[\mathrm{HCF}]} \\
\times 10^{4}\end{array}$ & $\begin{array}{c}\text { [L-Prol] } \\
\times 10^{3}\end{array}$ & {$\left[\mathrm{OH}^{-}\right]$} & $\underset{\times 10^{6}}{[\mathrm{Ru}(\mathrm{III})]}$ & \multicolumn{2}{|c|}{$\begin{array}{c}\mathbf{k}_{\text {obs }} \times 10^{3} \\
\left(\mathrm{~s}^{-1}\right)\end{array}$} \\
\hline$\left(\mathrm{mol} \mathrm{dm}^{-3}\right)$ & $\left(\mathrm{mol} \mathrm{dm}^{-3)}\right.$ & $\left(\mathrm{mol} \mathbf{d m}^{-3)}\right.$ & $\left(\mathrm{mol} \mathrm{dm}^{-3}\right)$ & Exptl. & Calc." $^{*}$ \\
\hline 0.6 & 4.0 & 0.02 & 1.0 & 2.55 & 2.55 \\
\hline 0.8 & 4.0 & 0.02 & 1.0 & 2.55 & 2.55 \\
\hline 1.0 & 4.0 & 0.02 & 1.0 & 2.54 & 2.55 \\
\hline 2.0 & 4.0 & 0.02 & 1.0 & 2.53 & 2.55 \\
\hline 3.0 & 4.0 & 0.02 & 1.0 & 2.55 & 2.55 \\
\hline 4.0 & 4.0 & 0.02 & 1.0 & 2.56 & 2.55 \\
\hline 5.0 & 4.0 & 0.02 & 1.0 & 2.62 & 2.55 \\
\hline 7.0 & 4.0 & 0.02 & 1.0 & 2.58 & 2.55 \\
\hline 4.0 & 1.0 & 0.02 & 1.0 & 2.53 & 2.55 \\
\hline 4.0 & 2.0 & 0.02 & 1.0 & 2.54 & 2.55 \\
\hline 4.0 & 3.0 & 0.02 & 1.0 & 2.53 & 2.55 \\
\hline 4.0 & 4.0 & 0.02 & 1.0 & 2.61 & 2.55 \\
\hline 4.0 & 5.0 & 0.02 & 1.0 & 2.56 & 2.55 \\
\hline 4.0 & 7.0 & 0.02 & 1.0 & 2.35 & 2.55 \\
\hline 4.0 & 10.0 & 0.02 & 1.0 & 2.45 & 2.55 \\
\hline 4.0 & 4.0 & 0.005 & 1.0 & 0.87 & 0.88 \\
\hline 4.0 & 4.0 & 0.010 & 1.0 & 1.61 & 1.60 \\
\hline 4.0 & 4.0 & 0.020 & 1.0 & 2.51 & 2.56 \\
\hline 4.0 & 4.0 & 0.030 & 1.0 & 3.72 & 3.93 \\
\hline 4.0 & 4.0 & 0.050 & 1.0 & 5.00 & 4.58 \\
\hline 4.0 & 4.0 & 0.080 & 1.0 & 6.24 & 6.69 \\
\hline 4.0 & 4.0 & 0.02 & 0.3 & 1.07 & 1.00 \\
\hline 4.0 & 4.0 & 0.02 & 0.5 & 1.66 & 1.40 \\
\hline 4.0 & 4.0 & 0.02 & 0.8 & 2.46 & 2.24 \\
\hline 4.0 & 4.0 & 0.02 & 1.0 & 2.62 & 2.56 \\
\hline 4.0 & 4.0 & 0.02 & 2.0 & 5.31 & 5.60 \\
\hline 4.0 & 4.0 & 0.02 & 3.0 & 8.76 & 8.40 \\
\hline
\end{tabular}

\# $\mathrm{k}_{\mathrm{obs}}$ were recalculated by using ' $\mathrm{k}$ ' and ' $\mathrm{K}_{1}$ ' as $1.06 \times 10^{4} \mathrm{dm}^{3} \mathrm{~mol}^{-1} \mathrm{~s}^{-1}$ and $18 \mathrm{dm}^{3}$ $\mathrm{mol}^{-1}$ respectively in the rate equation (6).

\subsection{Effect of Ionic Strength and Dielectric Constant}

Ionic strength of the reaction was studied by varying $\left[\mathrm{NaNO}_{3}\right]$ in the concentration range, 0.02 to $0.2 \mathrm{~mol} \mathrm{dm}^{-3}$ with fixed concentrations of oxidant, reductant, catalyst and alkali. It was found that the reaction was almost independent upon ionic strength.

The effect of change in dielectric constant (D) of the medium on the reaction rate was studied by increasing the percentage of t-butyl alcohol with water $(\mathrm{v} / \mathrm{v})$ of the reaction medium when all other reactants concentration and other conditions being constant. Earlier 'D' of the medium was calculated for different ratios (v/v) of t-butyl alcohol and water by using the ' $\mathrm{D}$ ' values of $\mathrm{H}_{2} \mathrm{O}$ and t-butyl alcohol in their pure state. The $\mathrm{k}_{\mathrm{obs}}$ were increased with increasing ' $\mathrm{D}$ ' of the medium. A plot of $\log \mathrm{k}_{\mathrm{obs}}$ versus $1 / \mathrm{D}$ was linear with a negative slope (Fig. 1).

Table 2. Effect of Initially Added Products, $\left[\mathrm{Fe}(\mathrm{CN})_{6}\right]^{4-}$ and [L-Glutamic Acid] and Added Salt, KCl on Oxidation of L-Proline by Hexacyanoferrate(III) Catalyzed by Ruthenium(III) in Aqueous Alkali at $25^{\circ} \mathrm{C}$
$[\mathrm{HCF}]=4.0 \times 10^{-4}$
$[$ L-Prol $]=4.0 \times 10^{-3}$
$[\mathrm{Ru}(\mathrm{III})]=1.0 \times 10^{-6}$
$\left[\mathrm{OH}^{-}\right]=0.02 \mathrm{I}=0.1 / \mathrm{mol} \mathrm{dm}^{-3}$

\begin{tabular}{|c|c|c|c|}
\hline$\left[\mathrm{Fe}(\mathrm{CN})_{6}\right]^{4-} \times 10^{4}$ & {$[$ L-glutamic acid $] \times 10^{4}$} & {$[\mathrm{KCl}] \times 10^{4}$} & $\mathbf{k}_{\mathrm{obs}} \times 10^{3}$ \\
\hline$\left.(\mathbf{m o l ~ d m})^{-3}\right)$ & $\left(\mathbf{m o l ~ d m} \mathbf{~ m}^{-3}\right)$ & $\left(\mathbf{m o l ~ d m}{ }^{-3}\right)$ & $\left(s^{-1}\right)$ \\
\hline 0.00 & - & - & 2.56 \\
\hline 0.80 & - & - & 1.13 \\
\hline 1.00 & - & - & 0.90 \\
\hline 2.00 & - & - & 0.54 \\
\hline 4.00 & - & - & 0.33 \\
\hline 7.00 & - & - & 0.21 \\
\hline- & 0.00 & - & 2.55 \\
\hline- & 0.80 & - & 2.56 \\
\hline- & 1.00 & - & 2.48 \\
\hline- & 2.00 & - & 2.49 \\
\hline- & 4.00 & - & 2.49 \\
\hline- & 7.00 & 0.00 & 2.56 \\
\hline- & - & 0.80 & 2.55 \\
\hline- & - & 1.00 & 2.55 \\
\hline- & - & 2.00 & 2.55 \\
\hline- & - & 4.00 & 2.55 \\
\hline- & - & 7.00 & 2.55 \\
\hline
\end{tabular}

\subsection{Test for Free Radicals (Polymerization Study)}

Intervention of free radical during oxidation of L-proline by single equivalent oxidant, HCF was studied by adding free radical scavenger, acrylonitrile, followed by dilution with methanol resulted non-perceptible precipitation. This appraises that free radical is not intervened in the reaction paths. It is also observed that the rate of reaction is unaltered by the addition of acrylonitrile.

\subsection{Effect of Temperature}

The rate of reaction was measured at different temperatures at constant concentrations of reactants and other conditions being constant. The rate of reaction was increased with increasing the temperature. The values of $\mathrm{k}_{\mathrm{obs}}$ at different temperature were tabulated (Table 3). The activation energy was calculated from the slope of Arrhenius 
plot of $\log \mathrm{k}_{\mathrm{obs}}$ versus $1 / \mathrm{T}$ and it is used to calculate other activation parameters (Table $\mathbf{3}$ ).

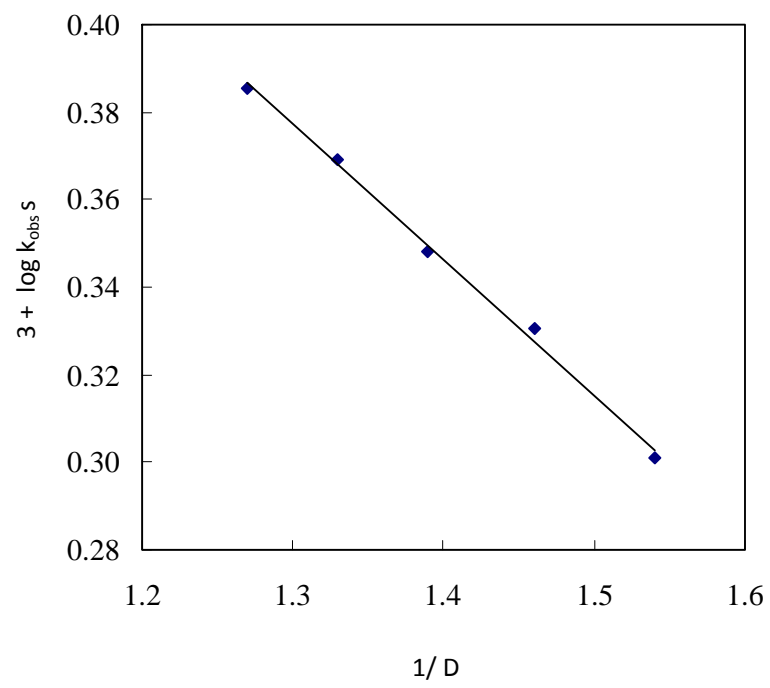

Fig. (1). Effect of variation of dielectric constant of the reaction medium on oxidation of L-Proline by hexacyanoferrate(III) catalyzed by ruthenium(III) in aqueous alkali at $25^{\circ} \mathrm{C}$.

Table 3. Effect of Variation of Ionic Strength and Dielectric Constant of the Reaction Medium on Oxidation of L-Proline by Hexacyanoferrate(III) Catalyzed by Ruthenium(III) in Aqueous Alkali at $25^{\circ} \mathrm{C}$
$[\mathrm{HCF}]=\mathbf{4 . 0} \times 10^{-4}$
$[\mathrm{L}-\mathrm{Prol}]=4.0 \times 10^{-3}$
$[\operatorname{Ru}($ III $)]=1.0 \times 10^{-6}$
$\left[\mathrm{OH}^{-}\right]=0.02 / \mathrm{mol} \mathrm{dm}^{-3}$

\begin{tabular}{|c|c|c|c|c|c|}
\hline \multicolumn{2}{|c|}{ Ionic Strength (I) } & \multicolumn{3}{c|}{ Dielectric Constant (D) } \\
\hline \multicolumn{3}{|c|}{$\mathbf{D}=\mathbf{7 8 . 5}$} & \multicolumn{3}{c|}{$\mathbf{I}=\mathbf{0 . 1} \mathbf{~ m o l ~ d m}^{-3}$} \\
\hline $\begin{array}{c}\mathbf{I} \\
\left(\mathbf{m o l ~ d m}^{-3}\right)\end{array}$ & $\sqrt{ } \mathbf{I}$ & $\begin{array}{c}\mathbf{k}_{\text {obs }} \mathbf{X} \mathbf{1 0}^{\mathbf{3}} \\
\left(\mathbf{s}^{-1}\right)\end{array}$ & $\begin{array}{c}\text { t-Butyl } \\
\text { Alcohol-Water } \\
(\%) \mathbf{v} / \mathbf{v}\end{array}$ & $\mathbf{D}$ & $\begin{array}{c}\mathbf{k}_{\text {obs } \mathbf{~ 1 0}} \\
\left(\mathbf{s}^{-1}\right)\end{array}$ \\
\hline \hline 0.02 & 0.14 & 2.33 & 0 & 78.5 & 2.43 \\
\hline 0.04 & 0.20 & 2.41 & 5 & 75.1 & 2.34 \\
\hline 0.05 & 0.22 & 2.42 & 10 & 71.7 & 2.23 \\
\hline 0.08 & 0.28 & 2.49 & 15 & 68.4 & 2.14 \\
\hline 0.1 & 0.32 & 2.52 & 20 & 65.0 & 2.00 \\
\hline 0.2 & 0.44 & 2.66 & --- & --- & -- \\
\hline
\end{tabular}

\subsection{Effect of [Ru(III)]}

At constant concentrations of $\mathrm{HCF}$, L-proline, $\mathrm{OH}^{-}$and ionic strength of $0.1 \mathrm{~mol} \mathrm{dm}^{-3}$, the $[\mathrm{Ru}(\mathrm{III})]$ was varied from $3.0 \times 10^{-7}$ to $3.0 \times 10^{-6} \mathrm{~mol} \mathrm{dm}^{-3}$ in the reaction. The rate of reaction was increased linearly with $[\mathrm{Ru}(\mathrm{III})]$ (Table $\mathbf{1})$. The order in $[\mathrm{Ru}(\mathrm{III})]$ was found to be unity.

\section{DISCUSSION}

Ruthenium(III) chloride has been extensively used as a catalyst in many redox reactions involving one or two equivalent oxidants [11-14] both in acid as well as in alkali. $\mathrm{Ru}(\mathrm{III})$ has $\mathrm{d}^{5}$ electronic configuration [19] and shows extensive coordination chemistry like forming stable cationic, neutral and anionic, six coordinated complexes etc. which are kinetically [20] inert. Aqueous solution of $\mathrm{RuCl}_{3}$ is existed in its chloride complexes viz., $\left[\mathrm{Ru}\left(\mathrm{H}_{2} \mathrm{O}\right)_{5} \mathrm{Cl}\right]^{2+}$, $\left[\mathrm{Ru}\left(\mathrm{H}_{2} \mathrm{O}\right)_{4} \mathrm{Cl}_{2}\right]^{+},\left[\mathrm{Ru}\left(\mathrm{H}_{2} \mathrm{O}\right)_{2} \mathrm{Cl}_{4}\right]^{-}$and $\left[\mathrm{RuCl}_{6}\right]^{3-}$ in addition to its aqueous species as $\left[\mathrm{Ru}\left(\mathrm{H}_{2} \mathrm{O}\right)_{6}\right]^{3+}$. The existence of $\mathrm{Ru}(\mathrm{III})$ in its chloride complexes are possible only when on heating [21] or aging in presence of higher concentration of HCl. In the present study, the fresh solutions were used and solutions prepared in low concentration of $\mathrm{HCl}$. Hence, such chloride complexes are excluded. Nevertheless, the alternative form of ruthenium(III) may be considered as $\left[\mathrm{Ru}\left(\mathrm{H}_{2} \mathrm{O}\right)_{6}\right]^{3+}$. As evidence, the added $\mathrm{Cl}^{-}$did not alter the rate of reaction and its UV-Visible spectrum was identical with reported study [20].

However, in alkaline medium, ruthenium(III) is known to exist [22] as its hydroxylated species with general formula $\left[\mathrm{Ru}(\mathrm{OH})_{\mathrm{x}}\left(\mathrm{H}_{2} \mathrm{O}\right)_{6-\mathrm{x}}\right]^{3-\mathrm{x}}$ where, $\mathrm{x}<6$ and variable, which is depending upon the $\left[\mathrm{OH}^{-}\right]$used. Under the present experimental conditions where $\left[\mathrm{OH}^{-}\right]>[\mathrm{Ru}(\mathrm{III})]$, it is mainly existed as $\left[\mathrm{Ru}\left(\mathrm{H}_{2} \mathrm{O}\right)_{5} \mathrm{OH}\right]^{2+}$ as shown in equation (2).

$$
\left[\mathrm{Ru}\left(\mathrm{H}_{2} \mathrm{O}\right)_{6}\right]^{3+}+\mathrm{OH}^{-} \stackrel{\mathrm{K}_{1}}{=}\left[\mathrm{Ru}\left(\mathrm{H}_{2} \mathrm{O}\right)_{5}(\mathrm{OH})\right]^{2+}+\mathrm{H}_{2} \mathrm{O}
$$

Hence, active species of ruthenium(III) is considered as $\left[\mathrm{Ru}\left(\mathrm{H}_{2} \mathrm{O}\right)_{5} \mathrm{OH}\right]^{2+}$. It is supported by a positive fractional order in $\left[\mathrm{OH}^{-}\right]$. The zero order dependency in [L-Prol], first order each in $[\mathrm{HCF}]$ and $[\mathrm{Ru}(\mathrm{III})]$, and fractional order in $\left[\mathrm{OH}^{-}\right]$can be accommodated in the following Scheme 1.

L-proline has two donor atoms viz., ' $\mathrm{N}$ ' from imino moiety and ' $\mathrm{O}$ ' from carboxylic group having lone pair of electrons. It is a known fact [19] that ' $\mathrm{N}$ ' is a small potent atom and the presence of two $-\mathrm{CH}_{2}$ groups on either side of ' $\mathrm{N}$ ' atom makes it easy to form a short lived adduct with $\mathrm{Ru}(\mathrm{V})$.

Hence, the $\mathrm{Ru}(\mathrm{V})$ may be involved [23] in the formation of adduct with L-proline through ' $\mathrm{N}$ ' atom in transition state or it is pertinent to note that the $\mathrm{Ru}(\mathrm{III}) / \mathrm{Ru}(\mathrm{IV}) / \mathrm{Ru}(\mathrm{V})$ are better hydride ion abstracter [24] than HCF, and also a fact that the test for intervention of free radicals was failed in polymerization study. Thus, the oxidation of L-proline could be occurred by losing hydride ion to $\mathrm{Ru}(\mathrm{V})$ in a fast step, followed by hydrolysis in the subsequent step to give glutamic semialdehyde [1].

Glutamic semialdehyde is less stable and further oxidizes to glutamic acid [1] in the similar way of hydride ion abstraction by $\mathrm{Ru}(\mathrm{V})$ which is formed by the oxidation of $\mathrm{Ru}(\mathrm{III})$ by HCF as presented in Schemes $\mathbf{1}$ and $\mathbf{2}$.

Mechanism as written in Schemes $\mathbf{1}$ and $\mathbf{2}$ are consistent with the experimentally observed facts of unit order each in $[\mathrm{Ru}(\mathrm{III})]$ and $[\mathrm{HCF}]$, and fractional order in $\left[\mathrm{OH}^{-}\right]$, and independence of rate on [L-Prol]. The zero order dependency of [L-Prol] is only subtle indication of interaction between HCF and L-proline in a slow or even in fast steps, as such interaction leads intervention of free radical, which was not observed. Further, the interaction between $\mathrm{Ru}(\mathrm{IV})$ and Lproline is also remote as such interaction may again lead to a free radical path. The unit order dependency each in oxidant 


$$
\begin{aligned}
& {\left[\mathrm{Ru}\left(\mathrm{H}_{2} \mathrm{O}\right)_{6}\right]^{3+}+\mathrm{OH}^{-} \stackrel{\mathrm{K}_{1}}{=}\left[\mathrm{Ru}\left(\mathrm{H}_{2} \mathrm{O}\right)_{5}(\mathrm{OH})\right]^{2+}+\mathrm{H}_{2} \mathrm{O}} \\
& {\left[\mathrm{Ru}\left(\mathrm{H}_{2} \mathrm{O}\right)_{5}(\mathrm{OH})\right]^{2+}+\left[\mathrm{Fe}(\mathrm{CN})_{6}\right]^{3-} \underset{\text { slow }}{\stackrel{\mathrm{k}}{\longrightarrow}}\left[\mathrm{Ru}\left(\mathrm{H}_{2} \mathrm{O}\right)_{5}(\mathrm{OH})\right]^{3+}+\left[\mathrm{Fe}(\mathrm{CN})_{6}\right]^{4-}} \\
& {\left[\mathrm{Ru}\left(\mathrm{H}_{2} \mathrm{O}\right)_{5}(\mathrm{OH})\right]^{3+}+\left[\mathrm{Fe}(\mathrm{CN})_{6}\right]^{3-} \stackrel{\text { fast }}{\longrightarrow}\left[\mathrm{Ru}\left(\mathrm{H}_{2} \mathrm{O}\right)_{5}(\mathrm{OH})\right]^{4+}+\left[\mathrm{Fe}(\mathrm{CN})_{6}\right]^{4-}} \\
& \begin{array}{rl}
{\left[\mathrm{Ru}\left(\mathrm{H}_{2} \mathrm{O}\right)_{5}(\mathrm{OH})\right]^{4+}+\mathrm{N}_{\mathrm{N}}} & \mathrm{COOH}+\mathrm{OH}^{-} \stackrel{\mathrm{N}}{\mathrm{H}} \stackrel{\mathrm{COOH}}{\longrightarrow} \\
& +\left[\mathrm{Ru}\left(\mathrm{H}_{2} \mathrm{O}\right)_{4}(\mathrm{OH})(-\mathrm{H})\right]^{3+}+2 \mathrm{H}_{2} \mathrm{O}
\end{array}
\end{aligned}
$$

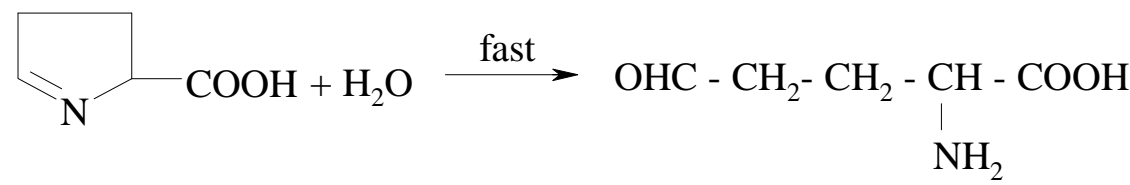

$$
\begin{aligned}
& {\left[\mathrm{Ru}\left(\mathrm{H}_{2} \mathrm{O}\right)_{4}(\mathrm{OH})(-\mathrm{H})\right]^{3+}+\mathrm{OH}^{-} \stackrel{\text { fast }}{\longrightarrow}\left[\mathrm{Ru}\left(\mathrm{H}_{2} \mathrm{O}\right)_{5}(\mathrm{OH})\right]^{2+}}
\end{aligned}
$$

Scheme 1.

$$
\begin{aligned}
& {\left[\mathrm{Ru}\left(\mathrm{H}_{2} \mathrm{O}\right)_{5}(\mathrm{OH})\right]^{2+}+2\left[\mathrm{Fe}(\mathrm{CN})_{6}\right]^{3-} \stackrel{\text { fast }}{\longrightarrow}\left[\mathrm{Ru}\left(\mathrm{H}_{2} \mathrm{O}\right)_{5}(\mathrm{OH})\right]^{4+}+2\left[\mathrm{Fe}(\mathrm{CN})_{6}\right]^{4-}} \\
& \text { OHC }-\mathrm{CH}_{2}-\mathrm{CH}_{2}-\underset{\mid}{\mathrm{CH}-\mathrm{COOH}}+\left[\mathrm{Ru}\left(\mathrm{H}_{2} \mathrm{O}\right)_{5}(\mathrm{OH})\right]^{4+}+\mathrm{OH}^{-} \stackrel{\text { fast }}{\longrightarrow} \underset{\mathrm{NH}_{2}}{\mathrm{HOOC}-\mathrm{CH}_{2}-\mathrm{CH}_{2}-\underset{\mid}{\mathrm{CH}}-\mathrm{COOH}} \\
& +\left[\mathrm{Ru}\left(\mathrm{H}_{2} \mathrm{O}\right)_{4}(\mathrm{OH})(-\mathrm{H})\right]^{3+}+2 \mathrm{H}_{2} \mathrm{O} \\
& {\left[\mathrm{Ru}\left(\mathrm{H}_{2} \mathrm{O}\right)_{4}(\mathrm{OH})(-\mathrm{H})\right]^{3+}+\mathrm{OH}^{-} \stackrel{\text { fast }}{\longrightarrow}\left[\mathrm{Ru}\left(\mathrm{H}_{2} \mathrm{O}\right)_{5}(\mathrm{OH})\right]^{2+}+\mathrm{H}_{2} \mathrm{O}}
\end{aligned}
$$

\section{Scheme 2.}

and catalyst reveals that reaction follows outer spheremechanism. The large value of $\log$ A (10.6) is a supportive fact for the same, and the magnitude 10.6 shows that the oppositely charged ions such as $\left[\mathrm{Ru}\left(\mathrm{H}_{2} \mathrm{O}\right)_{5}(\mathrm{OH})\right]^{2+}$ and $\left[\mathrm{Fe}(\mathrm{CN})_{6}\right]^{3-}$ are interacting in the slow step.

The retarding effect on the rate by initial addition of the product, hexacyanoferrate(II) is not shown in Scheme 1. This retarding effect may be due to the secondary salt effect [25] as oppositely charged species $\left[\mathrm{Ru}\left(\mathrm{H}_{2} \mathrm{O}\right)_{5}(\mathrm{OH})\right]^{2+}$ and $\mathrm{Na}\left[\mathrm{Fe}(\mathrm{CN})_{6}\right]^{2-}$ are involved in a slow step or it may readily form a complex with substrate/ glutamic semialdehyde which may be less reactive than the L-proline and/or glutamic semialdehyde alone.

The ion paired species like $\mathrm{Na}\left[\mathrm{Fe}(\mathrm{CN})_{6}\right]^{2-}$ may be formed in situ, by interacting $\left[\mathrm{Fe}(\mathrm{CN})_{6}\right]^{3-}$ with $\mathrm{Na}^{+}$of aqueous solutions of $\mathrm{NaNO}_{3}$ and $\mathrm{NaOH}$. Similar type of ion pairing between $\mathrm{K}^{+}$and $\left[\mathrm{Fe}(\mathrm{CN})_{6}\right]^{3-}$ was observed [26].

The rate law is not derived for Scheme $\mathbf{2}$ as intermediates are formed in fast steps. Nevertheless, the rate law for Scheme 1 can be derived as 


$$
\begin{aligned}
-\frac{\mathrm{d}\left[\mathrm{Fe}(\mathrm{CN})_{6}\right]^{3 .}}{\mathrm{dt}}= & \text { rate }=\mathrm{k}\left[\mathrm{Fe}(\mathrm{CN})_{6}\right]^{3-}\left[\mathrm{Ru}\left(\mathrm{H}_{2} \mathrm{O}\right)_{5}(\mathrm{OH})\right]^{2+} \\
& =\mathrm{kK}_{1}\left[\mathrm{Ru}\left(\mathrm{H}_{2} \mathrm{O}\right)_{6}\right]_{\mathrm{f}}^{3+}\left[\mathrm{Fe}(\mathrm{CN})_{6}\right]_{\mathrm{f}}^{3+}\left[\mathrm{OH}^{3}\right]_{\mathrm{f}}
\end{aligned}
$$

However,

$[\mathrm{Ru}(\mathrm{III})]_{\mathrm{T}}=\left[\mathrm{Ru}\left(\mathrm{H}_{2} \mathrm{O}\right)_{6}\right]_{\mathrm{f}}^{3+}+\left[\mathrm{Ru}\left(\mathrm{H}_{2} \mathrm{O}\right)_{5}(\mathrm{OH})\right]^{2+}{ }_{\mathrm{f}}$

The other species of $\mathrm{Ru}(\mathrm{III})$ complexes like $\left[\mathrm{Ru}\left(\mathrm{H}_{2} \mathrm{O}\right)_{5} \mathrm{Cl}\right]^{2+}, \quad\left[\mathrm{Ru}\left(\mathrm{H}_{2} \mathrm{O}\right)_{4} \mathrm{Cl}_{2}\right]^{+}, \quad\left[\mathrm{Ru}\left(\mathrm{H}_{2} \mathrm{O}\right)_{2} \mathrm{Cl}_{4}\right]^{-}$and $\left[\mathrm{RuCl}_{6}\right]^{3-}$ are omitted and equation 2 is considered for the calculation of $[\mathrm{Ru}(\mathrm{III})]_{\mathrm{T}}$

$$
\begin{aligned}
{[\mathrm{Ru}(\mathrm{III})]_{\mathrm{T}} } & =\left[\mathrm{Ru}\left(\mathrm{H}_{2} \mathrm{O}\right)_{6}\right] f^{3+}+\mathrm{K}_{1}\left[\mathrm{Ru}\left(\mathrm{H}_{2} \mathrm{O}\right)_{6}\right]^{3+}\left[\mathrm{OH}^{-}\right]_{\mathrm{f}} \\
& =\left[\mathrm{Ru}\left(\mathrm{H}_{2} \mathrm{O}\right)_{6}\right]_{\mathrm{f}}^{3+}\left\{1+\mathrm{K}_{1}\left[\mathrm{OH}^{-}\right]_{\mathrm{f}}\right\} \\
{\left[\mathrm{Ru}\left(\mathrm{H}_{2} \mathrm{O}\right)_{6}\right]_{\mathrm{f}}^{3+} } & =\frac{[\mathrm{Ru}(\mathrm{III})]_{\mathrm{T}}}{1+\mathrm{K}_{1}\left[\mathrm{OH}^{-}\right]_{\mathrm{f}}}
\end{aligned}
$$

By substituting equation (4) in equation (3), the equation (5) results

Rate $=-\frac{\mathrm{d}\left[\mathrm{Fe}(\mathrm{CN})_{6}\right]^{3 .}}{\mathrm{dt}}=\frac{\mathrm{kK}_{1}\left[\mathrm{Fe}(\mathrm{CN})_{6}\right]^{3-\mathrm{r}}[\mathrm{Ru}(\mathrm{III})]_{\uparrow}\left[\mathrm{OH}^{-}\right]_{\Gamma}}{1+\mathrm{K}_{1}\left[\mathrm{OH}^{-}\right]_{\mathrm{f}}}$

The subscripts ' $\mathrm{f}$ ' and ' $\mathrm{T}$ ' are omitted for the verification of rate law.

Hence,

$$
\begin{aligned}
& k_{\text {obs }}=\frac{k_{1}[\mathrm{Ru}(\mathrm{III})]\left[\mathrm{OH}^{-}\right]}{1+\mathrm{K}_{1}\left[\mathrm{OH}^{-}\right]} \\
& \frac{1}{k_{\text {obs }}}=\frac{1}{\mathrm{kK}_{1}[\mathrm{Ru}(\mathrm{III})]\left[\mathrm{OH}^{-}\right]}+\frac{1}{\mathrm{k}[\mathrm{Ru}(\mathrm{III})]}
\end{aligned}
$$

Equation (7) is verified by plotting $1 / \mathrm{k}_{\mathrm{obs}}$ versus $1 /\left[\mathrm{OH}^{-}\right]$ (Fig. 2). From the slope and intercept of such plot, the reaction constants, ' $\mathrm{k}$ ' and ' $\mathrm{K}$ ' were calculated as $1.06( \pm$ $0.04) \times 10^{4} \mathrm{dm}^{3} \mathrm{~mol}^{-1} \mathrm{~s}^{-1}$ and $18( \pm 0.5) \mathrm{dm}^{3} \mathrm{~mol}^{-1}$ respectively. These constants were used to calculate $\mathrm{k}_{\text {cald. }}$ under different experimental conditions and were found to be in close agreement with experimental results (Table 1).

Increase in the rate with increase in dielectric constant (D) of the medium is in expected direction [27] as ionic species are involved in the transition state to form activated complex. This activated complex might be more solvated in polar solvent like water than its reactants in a lower dielectric constant of the medium.

The large positive value of $\Delta \mathrm{S}^{\#}, 135 \mathrm{JK}^{-1} \mathrm{~mol}^{-1}$ indicates [28] that activated complex might have gained more degrees of freedom than its reactants, which might be highly disordered. This magnitude also explains the involvement of interaction between two oppositely charged ions in the rate

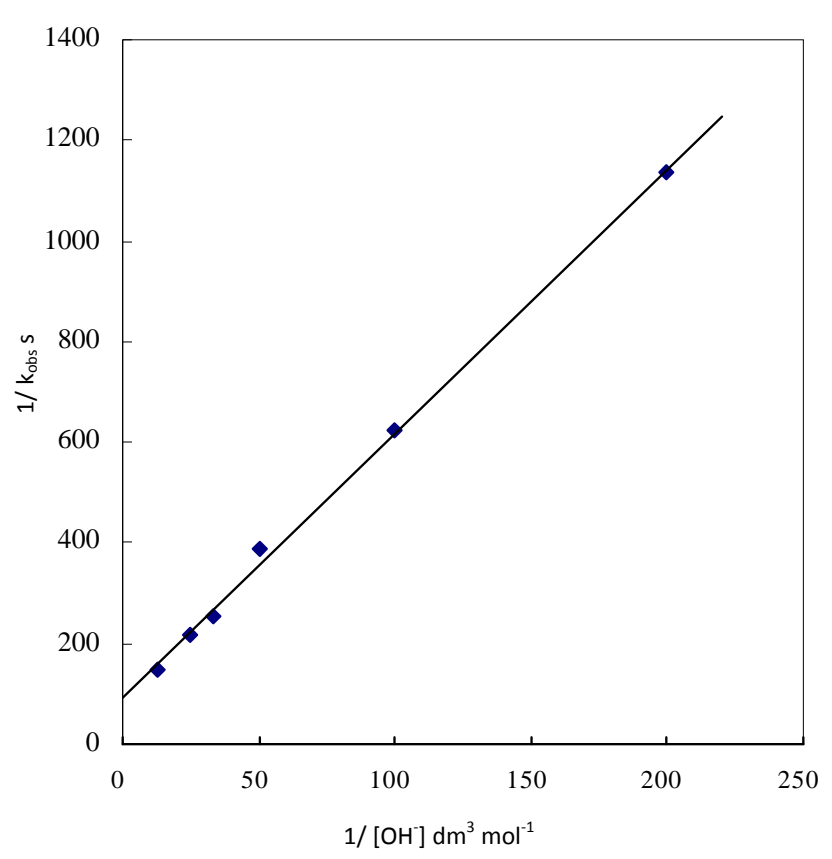

Fig. (2). Verification of rate law (9) at different $\left[\mathrm{OH}^{-}\right]$on oxidation of L-Proline by hexacyanoferrate(III) catalyzed by ruthenium(III) in aqueous alkali at $25^{\circ} \mathrm{C}$.

Table 4. A. Effect of Temperature on the Rate of Oxidation of L-Proline by Hexacyanoferrate(III) Catalyzed by Ruthenium(III) in Aqueous Alkali

$$
\begin{array}{ll}
{[\mathrm{HCF}]=4.0 \times 10^{-4}} & {[\mathrm{~L}-\mathrm{Prol}]=4.0 \times 10^{-3}} \\
{[\mathrm{Ru}(\mathrm{III})]=1.0 \times 10^{-6}} & {\left[\mathrm{OH}^{-}\right]=0.02 \mathrm{I}=0.1 / \mathrm{mol} \mathrm{dm}^{-3}}
\end{array}
$$

\begin{tabular}{|c|c|}
\hline Temp. $(\mathbf{K})$ & $\mathbf{k}_{\mathbf{o b s}} \mathbf{\times} \mathbf{1 0}^{\mathbf{3}}\left(\mathbf{s}^{\mathbf{- 1}}\right)$ \\
\hline \hline 298 & 2.54 \\
\hline 303 & 3.63 \\
\hline 308 & 5.50 \\
\hline 313 & 7.76 \\
\hline 318 & 12.0 \\
\hline
\end{tabular}

B. Activation Parameters of Oxidation of L-Proline by Hexacyanoferrate(III) Catalyzed by Ruthenium(III) in Aqueous Alkali

\begin{tabular}{|c|c|}
\hline Activation Parameters & Values \\
\hline \hline $\mathrm{E}_{\mathrm{a}}\left(\mathrm{kJ} \mathrm{mol}^{-1}\right)$ & $76.5 \pm 2$ \\
\hline$\Delta \mathrm{H}^{\#}\left(\mathrm{~kJ} \mathrm{~mol}^{-1}\right)$ & $74 \pm 2$ \\
\hline$\Delta \mathrm{S}^{\#}\left(\mathrm{~J} \mathrm{~K}^{-1} \mathrm{~mol}^{-1}\right)$ & $+135 \pm 5$ \\
\hline$\Delta \mathrm{G}^{\#}\left(\mathrm{~kJ} \mathrm{~mol}^{-1}\right)$ & $33 \pm 1$ \\
\hline $\operatorname{log~A}$ & $10.6 \pm 0.2$ \\
\hline
\end{tabular}

determining step. Due to this, large positive value of $\Delta S^{\#}$, the activated complex may be decomposed to give products at a 
faster rate, which is also evidenced by relatively large magnitude of ' $\mathrm{k}$ ' value $1.06( \pm 0.04) \times 10^{4} \mathrm{dm}^{3} \mathrm{~mol}^{-1} \mathrm{~s}^{-1}$. The large value of frequency factor also supports this fact. Although the first half of the mechanism in Scheme $\mathbf{1}$ and rate law (7) are similar [11] to the oxidation of Gabapentin by alkaline hexacyanoferrate(III) catalyzed by ruthenium(III), the other supporting kinetic parameters viz., retarding effect of initially added ferrocyanide, large positive values of $\Delta S^{\#}$ and $\log A(10.6)$ and positive dependency of rate with dielectric constant of the medium etc. are found to be un-identical with the earlier investigation [11]. The results obtained in the present study explain the mechanism of Scheme 1.

Moreover, this studies mainly emphasis the pyrrolidine ring cleavage in L-proline. The reports available in literature on oxidation of L-proline by various oxidants reveal [2] that, the pyrrolidine ring cleavage take place at $\alpha$-carbon atom between - NH- and - $\mathrm{CH}$ - to yield 2-amino butaraldehyde and 2-amino butyric acid. The reports on oxidation of D-proline by hexacyanoferrate(III) reveals that the formation of keto acid by deamination was due to the rupturing of covalent bond at the same position of carbon atom in pyrrolidine ring.

However, in the present investigation, mechanism of Scheme $\mathbf{2}$ and second half of mechanism of Scheme $\mathbf{1}$ is reported to be dissimilar to the earlier work [2] and product obtained in the present study was found to be glutamic acid which is not identical to the reported [2] results. Apart from these, the results obtained in the Os(VIII) catalysis were largely different. Hence, the study of oxidation of L-proline is found to be worth investigation.

\section{CONCLUSION}

Ruthenium(III) catalyzed, hexacyanoferrate(III) oxidation of L-proline in aqueous alkaline medium was found to be first order each in oxidant and catalyst where as zero order in substrate. The fractional order in $\left[\mathrm{OH}^{-}\right]$ explains the formation of hydroxylated species of $\mathrm{Ru}(\mathrm{III})$ as $\left[\mathrm{Ru}\left(\mathrm{H}_{2} \mathrm{O}\right)_{5}(\mathrm{OH})\right]^{2+}$ in the pre-equilibrium step before rate determining step. Unit order each in catalyst and oxidant indicate that reaction occurs through an outer-sphere mechanism wherein direct electron transfer takes place without intact with each other.

The results in the present study are found to be substantially different from earlier reports as L-proline has resulted glutamic acid as oxidative product. The previous reports reveal that the products were 4-amino butaraldehyde, 4-amino butyric acid and keto acids. Ru(III) was found to be acted as hydride ion abstracter which was evidenced by the non free radical path. When there is a zero order in [substrate], one of the added products $\left[\mathrm{Fe}(\mathrm{CN})_{6}\right]^{4-}$ had a retarding effect which is an unusual fact found in the reaction.

Oxidation of L-proline by alkaline hexacyanoferrate(III) in ruthenium(III) was followed without intervention of free radicals, whereas in Osmium(VIII) catalysis [29], the oxidation was occurred through intervention of free radicals. Hence, mechanism proposed for both the studies are different.

\section{REFERENCES}

[1] Nelson, D. L.; Cox, M. M. Lehninger Principles of Biochemistry, $4^{\text {th }}$ ed., W.H. Freeman and company, New York, 2007.

[2] Hiremath, C. V.; Kiran, T. S.; Nandibewoor, S. T. Os(VIII)/Ru(III) catalyzed oxidation of aspirin drug by a new oxidant, Diperiodatoargentate(III) in aqueous alkaline medium: A comparative kinetic study. J. Mol. Catal., A., 2006, 248, 163-174.

[3] List, B.; Lerner, R.A.; Barbes, C.F. Proline-catalyzed direct asymmetric aldol reactions. J. Am. Chem. Soc., 2000, 122, 23952398.

[4] Day, M.C.; Selbin, J. Theoretical Inorganic Chemistry, Reinhold, New York 1964.

[5] Lancaster, M.; Murray, R.S. The ferricyanide-sulphite reaction. $J$. Chem. Soc. A, 1971, $2755-2758$.

[6] Martinez, M.; Pitarque, M.; Eldik, R.V. Outer-sphere redox reactions of $\left[\mathrm{CoIII}\left(\mathrm{NH}_{3}\right)_{5}(\mathrm{Hx}\right.$ Py Oz) $](\mathrm{m}-3)$ - complexes. A temperature and pressure -dependence kinetic study on the influence of the phosphorous oxoanions. J. Chem. Soc. Dalton Trans, 1996, 2665-2669.

[7] Kelson, E.P.; Phengsy, P.P. Kinetic study of 2-propanol and benzyl alcohol oxidation by alkaline hexacyanoferrate(iii) catalyzed by a terpyridyl ruthenium complex. Int. J. Chem. Kinet., 2000, 32, 760770 .

[8] Vovk, A.I.; Muraveva, I.V.; Kukhar, V.P.; Baklan, V.F. Kinetics of oxidation of vitamin $b_{1}$ and its 0 -acyl analogs with ferricyanide - a mechanistic model of thiamin - binding protein. Russ. J. Gen. Chem., 2000, 70, 1108-1112.

[9] Speakman, P.T.; Waters, W.A. Kinetic features of the oxidation of aldehydes, ketones, and nitroparaffins with alkaline ferricyanide. $J$. Chem. Soc., 1955, 40-50.

[10] Tuwar, S.M.; Nandibewoor, S.T.; Raju, J.R. Oxidation of chromium(III) by alkaline Hexacyanoferrate(III). Tran. Met. Chem., 1991, 16, 335-338.

[11] Vijayasri, K.; Rajaram, J.; Kuriacose, J.C. Ruthenium(III) catalyzed oxidation of 1-phenylethanol and substituted 1-phenylethanols by phenyliodosoacetate. J. Chem. Sci., 1985, 95, 573.

[12] Jose, T.P.; Angadi, M.A.; Salunke, M.S.; Tuwar, S.M. Oxidative study of gabapentin by alkaline hexacyanoferrate(iii) in room temperature in presence of catalytic amount of ru(iii) - a mechanistic approach. J. Mol. Struct. 2008, 892, 121-124.

[13] Manikyamba, P. Ru(III) - catalyzed oxidation of pyruvic acid by iodate -A kinetic study. React. Kinet. Catal. Lett. 2003, 78, 168 171.

[14] Singh, H.S.; Singh, R.K.; Singh, S.M.; Sisodia, A.K. Kinetics and mechanism of the ruthenium(III) chloride catalyzed oxidation of butan-2-ol and methyl-1-propanol by the hexacyanoferrate(III) ion in an aqueous alkaline medium. J. Phys. Chem., 1977, 81, 10441049.

[15] Mendham, J.; Denney, R.C.; Barnes, J.D.; Thomas, M.J.K. Vogel's Text Book of Quantitative Chemical Analysis. 6th ed. Pearson Education, New Delhi, 2003.

[16] Wilson, K.; Walker, J. Practical Biochemistry. 5th ed. Cambridge University Press, Cambridge, UK, 2005.

[17] Hosamani, R.R.; Nandibewoor, S.T. Mechanistic study of ruthenium (III) catalyzed oxidation of L-lysine by diperiodatoargentate(III) in aqueous alkaline medium. J. Chem. Sci., 2009, 121, 275.

[18] Feigl, F. Spot Tests in Organic Analysis. Elsevier, New York, 1975.

[19] Sethuram, B. Some Aspects of Electron Transfer Reactions Involving Organic Molecules. Allied Publishers, New Delhi, 2003.

[20] Cotton, F.A.; Wilkinson, G. Advanced Inorganic Chemistry- A Comprehensive Text. 6th ed. Wiley Interscience, New York, 1996.

[21] Cady, H. H.; Conick, R. E. The Determination of the Formulas of Aqueous Ruthenium(III) Species by Means of Ion-exchange Resin: $\mathrm{Ru}^{+3}, \mathrm{RuCl}^{+2}$ and $\mathrm{RuCl}_{2}^{+}$. J. Am. Chem. Soc., 1958, 80, 2646-2650.

[22] Uma, V.; Sethuram, B.; Navaneeth Rao, T. Kinetics of oxidation of isopropanol by $\mathrm{IO}_{4}^{-}$catalyzed by metal ions. React. Kinet. Catal. Lett. 1981, 18, 283-288.

[23] Vijayasri, K.; Rajaram, J.; Kuriacose, J.C. Spectral evidence for the formation of active intermediates from $\mathrm{RuCl}_{3}$ and $\mathrm{RuCl}_{2}\left(\mathrm{PPh}_{3}\right)_{3}$ with $\quad N$-methylmorpholine $N$-oxide (NMO) and phenyliodosoacetate (PIA) as mild oxidants. Inorg. Chim. Acta, 1986, 117, 133-135.

[24] Kumar, P.; Gupta, K.C.; Vehari, K. Ruthenium(VI) catalyzed oxidation of sodium salts of lactic, tartaric and glycolic acid by 
alkaline hexacyanoferrate(III). React. Kinet. Catal. Lett. 1985, 29, 297-300.

[25] Swinehart, J.H. The Kinetics of the hexacyanoferrate(III)-Sulphite Reaction. J. Inorg. Nucl. Chem., 1967, 29, 2313 - 2320.

[26] Jose, T.P.; Nandibewoor, S.T.; Tuwar, S.M. Osmium(VIII) catalyzed oxidation of a sulfur containing amino acid - A kinetic and mechanistic Approach. J. Sulfur Chem., 2006, 27, 25-36.
[27] Laidler, K.J. Chemical Kinetics. 3rd ed. Pearson education, Delhi, India, 2004, p. 191.

[28] Frost, A. A.; Pearson, R. G. Kinetics and Mechanism. 2nd ed. Wiley Eastern Private Ltd., New Delhi, 1970, p. 133.

[29] Sharanabasamma, K.; Angadi, M. A.; Salunke, M. S.; Tuwar, S. M Osmium(VIII) catalyzed oxidative cleavage of pyrrolidine ring in L-proline by hexacyanoferrate(III) in alkaline media. Ind. Eng. Chem. Res., 2009, 48, 10381-10386.

(C) Sharanabasamma et al.; Licensee Bentham Open.

This is an open access article licensed under the terms of the Creative Commons Attribution Non-Commercial License (http://creativecommons.org/licenses/by-nc/ $3.0 /$ ) which permits unrestricted, non-commercial use, distribution and reproduction in any medium, provided the work is properly cited 